\title{
Cloud Distributions near the Periphery of a Convergence Zone in the Tropical Region*
} Clouds over the Pacific Ocean: Part VI

\author{
By Choji Magono and Chiyu Tik \\ Department of Geophysics, Hokkaido University, Sapporo, Japan \\ (Manuscript received 1 January 1969, in revised form 8 August 1969)
}

\begin{abstract}
Cloud observations were made over the Gulf of Siam, using a passenger flight airplane.

Several ring-shaped cloud distributions were observed near the periphery of a convergence zone, and it was considered that they were not look like the usual Benard's cell type motion, but were produced by a several downward air motion near the periphery of the convergence zone.

$\mathrm{A} \mathrm{Cb}$ cloud and a characteristic towering cumulus cloud with cloud bands of starfish-like form were observed. An effective sucking area with about $60 \mathrm{~km}$ diameter for the $\mathrm{Cb}$ or the towering cloud was estimated from the cloud band distribution.
\end{abstract}

\section{Introduction}

As a part of the "Study on Clouds over the Pacific Ocean", an observation flight to obtain cloud distribution over the West Pacific Ocean and the Southwest Asia was made on 7 th October 1965 on the return route of the previous observation (Magono, Kikuchi and Kasai, 1969). The photographing conditions were the same as used in the previous observation except that the $16 \mathrm{~mm}$ movie camera was set up on the starboard side of the observation airplane. And pictures of standard $35 \mathrm{~mm}$ size were used to record detailed cloud distributions. The flight altitude was at a constant height of 9,750 meters between Kota Bahru and Bangkok. The mean ground speed was 248 meters per second throughout the flight.

This paper will describe some interesting results obtained from the observation of cloud distribution over the Gulf of Siam. The method used for the cloud analysis was the same as that reported in the previous paper.

\section{Results of cloud observation}

The airplane left the Singapore International Airport at $06: 47 \mathrm{Z}(14: 17$ LST) and arrived at the Bangkok International Airport at $08: 37 \mathrm{Z}$

*) This work was done by the support of the U.S.-Japan Cooperative Science Program.
(15: 37 LST). The flight path is shown by a dashed line and the area of the cloud analysis is shown by a dotted area in the center of Fig. 1a, respectively.

\subsection{Synoptic situation}

Many low-level clouds were distributed in the observation area. The $850 \mathrm{mb}$ weather chart for $12: 00 \mathrm{Z}(19: 00 \mathrm{LST})$ October 7th which was the nearest to the cloud observation time $(07: 00$ 08:37 Z) is shown in Fig. 1a. This chart was prepared by the Thai Meteorological Department, but it was lack of data of pressure distribution over the Bay of Bengal and the South China Sea. Therefor, data prepared by the Singapore Meteorological Service was superimposed on the same chart, as shown by broken lines in the figure.

It is seen in the chart that an anticyclone existed over the Gulf of Tongking and a small high, over the Malayan Peninsula. It is also seen that a cyclone existed over the North of Bay of Bengal, a depression, over the south end of the Indochina Peninsula, and another cyclone, near the Philippines Islands. A "Convergence Zone" was mapped on a line connecting these cyclones and the depression by the Singapore Meteorological Service. The area of cloud analysis was just south side of the convergence zone. Ac- 

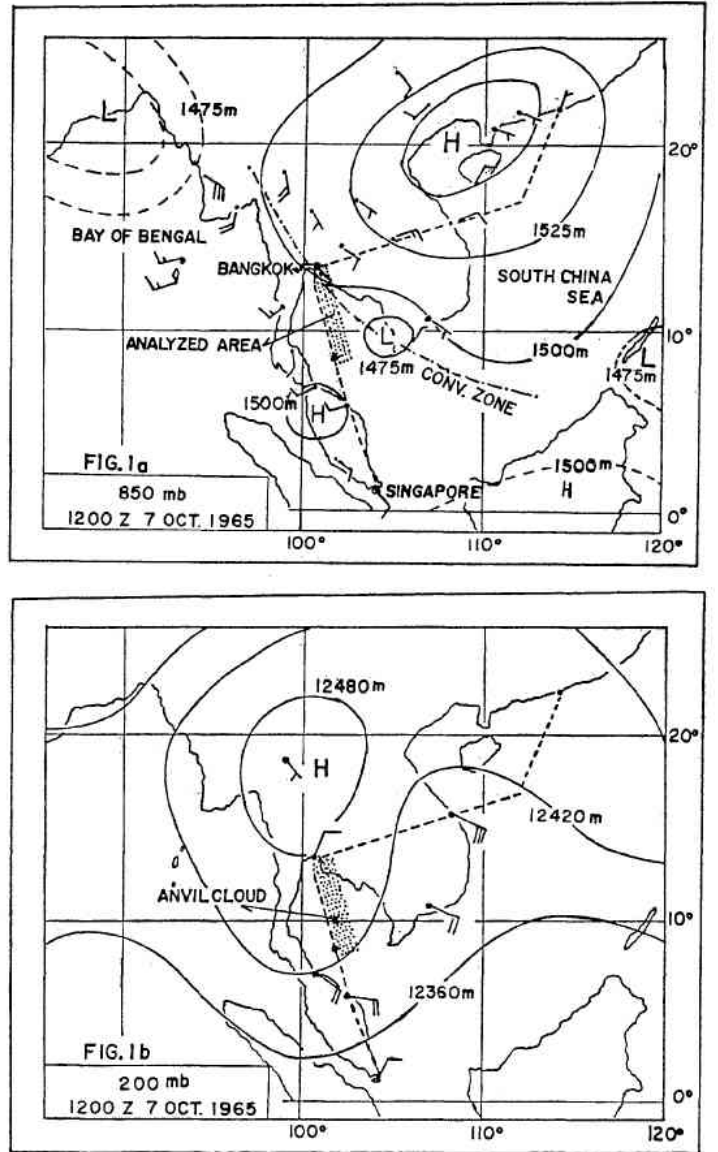

Fig. 1 Upper layer weater charts near the observation flight. The flight path is shown by a dashed line, and a convergence zone is mapped by a chain line.

cording to the chart, it is expected that southerly wind was prevailing at $850 \mathrm{mb}$ level in the observation area.

\subsection{Ring-shaped cloud distribution}

Clouds of characteristic distribution were observed, as shown in the photograph of Fig. 2.

Dense cirrostratus clouds higher than the flight height were distributed to the right side of the flight path, in other words along the convergence zone. A ring-shaped distribution of towering cumulus clouds was visible below the cirrostratus clouds, as shown in Photo. 1 in Fig. 2. The horizontal distribution of this ring-shaped cloud is mapped in the right end of Fig. 3 as indicated by $A$. The ring-shaped cloud existed below and near the periphery of the cirrostratus clouds. The major and minor axes of the ring were about 60 and $20 \mathrm{~km}$ respectively.

To the left of the ring-shaped distribution of the towering cumulus, several low-level cumulus cloud distributions of ring-shaped were seen, as shown in Photo. 2 in Fig. 2 and the locations are indicated by $B, C$ and $D$ in Fig. 3, although $D$ is not included in the photograph. The height of these cumulus cloud base was at $850 \mathrm{mb}$ level.

The size of the ring $B$ and $C$ was about $40 \mathrm{~km}$ in the major axis and $20 \mathrm{~km}$ in the minor axis respectively, and the size of ring $D$ was about $20 \mathrm{~km}$ in the major axis and $10 \mathrm{~km}$ in the minor respectively. It is seen that the directions of the major axes were parallel to the longitudinal lines, in other words parallel to the prevailing wind direction at this level.

\subsection{A cumulonimbus cloud with a huge anvil}

A cumulonimbus cloud with a huge anvil as shown in Photo. 3 in Fig. 2 was observed on the north side of the group of the ring-shaped lowlevel cloud distributions. A rainfall was seen under the anvil. The horizontal view of the cloud is given in Fig. 3. The anvil was extended about $40 \mathrm{~km}$ in a sector form towards the observation point, namely to the west. The height of the top of the anvil was about $200 \mathrm{mb}$ level $(12 \mathrm{~km})$. According to the $200 \mathrm{mb}$ chart of Fig. $1 \mathrm{~b}$, it is expected that the wind was easterly at the level. The direction of the anvil agreed with the direction of wind flow at the level.

Several low-level cumulus cloud bands roughly parallel to longitudinal lines were observed, as seen in the left side of Photo. 3 in Fig. 2, and in the left side of the $\mathrm{Cb}$ cloud in Fig. 3. These cloud bands seemed to converge into the root of the $\mathrm{Cb}$ cloud. And individual cloud element of the bands seemed to be distributed on the circles of various radii around the root of the $\mathrm{Cb}$ cloud. The area of the convergence was about $60 \mathrm{~km}$ in the diameter, as indicated by a dotted semi-circle in Fig. 3.

\subsection{A towering cumulus with starfish-like roots}

A towering cloud of characteristic form as shown in Photo. 4 was observed above the right entrance of the Bight of Bangkok $\left(13^{\circ} \mathrm{N}, 101^{\circ} \mathrm{E}\right)$. The top of the cloud reached and penetrated the dense high cirrostratus cloud layer. Its horizontal view is shown in Fig. 4. The shaded area in the figure means the penetrated portion of cloud 
Fig. 2 Aerial pictures of clouds over the Gulf of Siam.

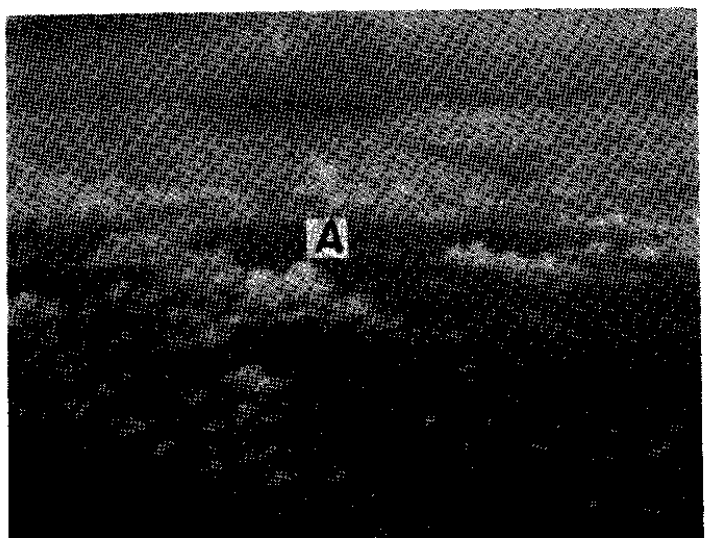

Photo. 1. Ring-shaped cloud distribution of towering cumulus cloud, indicated by $\mathbf{A}$.

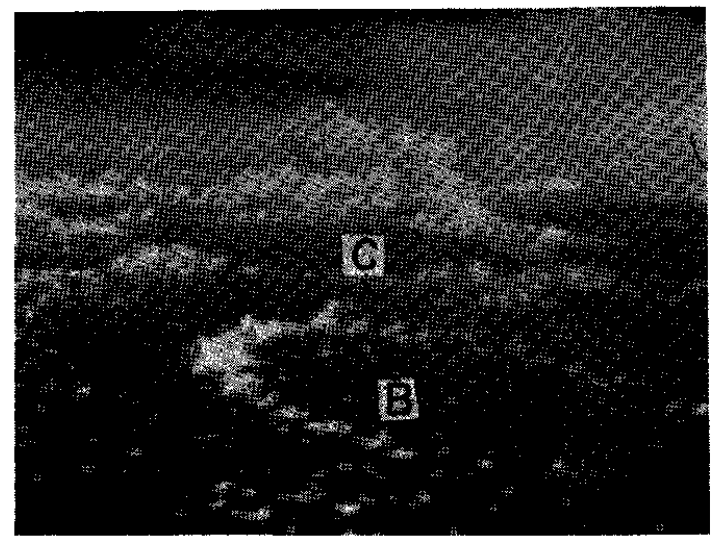

Photo. 2. Ring-shaped cloud distribution of low-level cumulus clouds, indicated by $B$ and $C$.

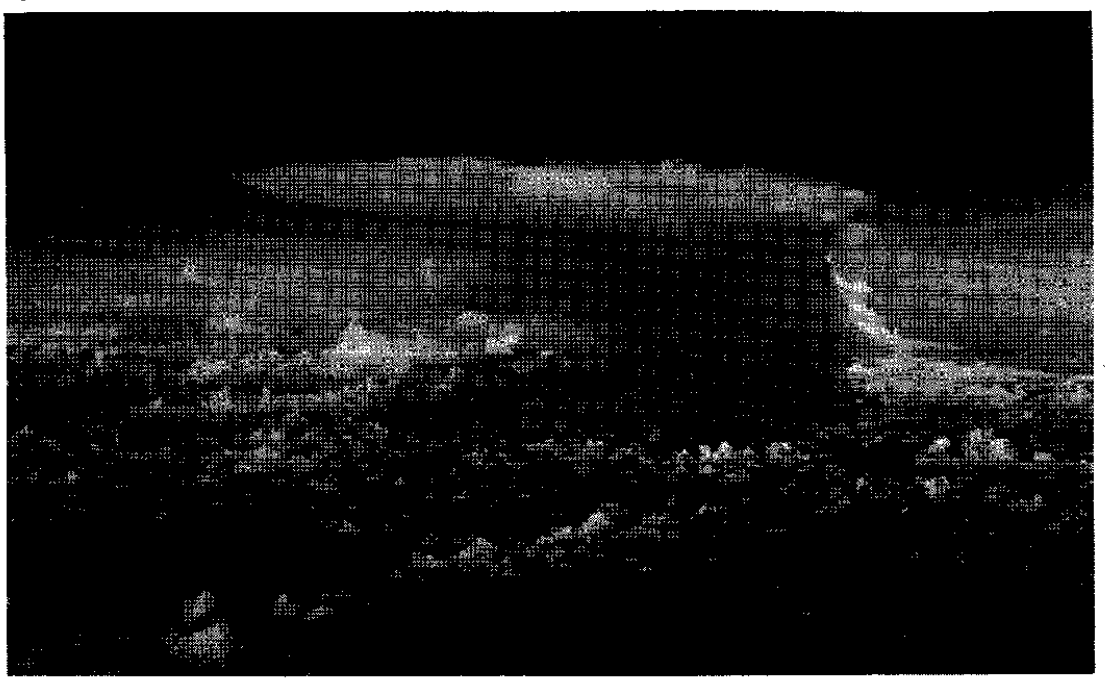

Photo. 3. A cumulonimbus with a huge anvil, and cloud streets around the cumulonimbus.

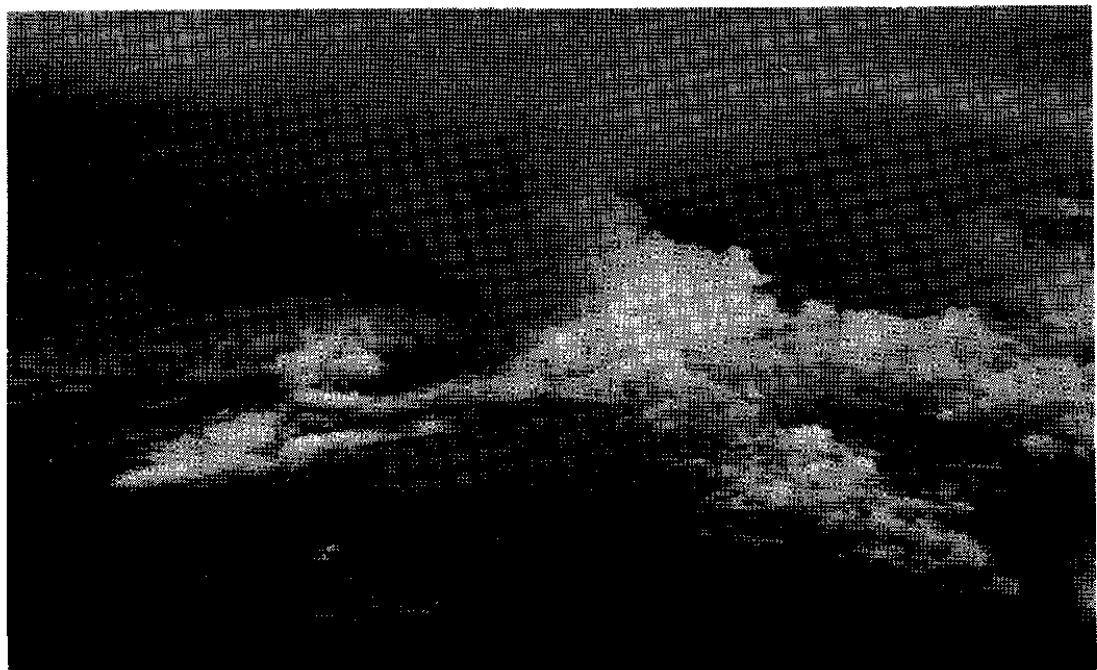

Photo. 4. A starfish-like cloud distribution. A towering cloud extended from the center of the distribution and reached the upper Sc cloud. 


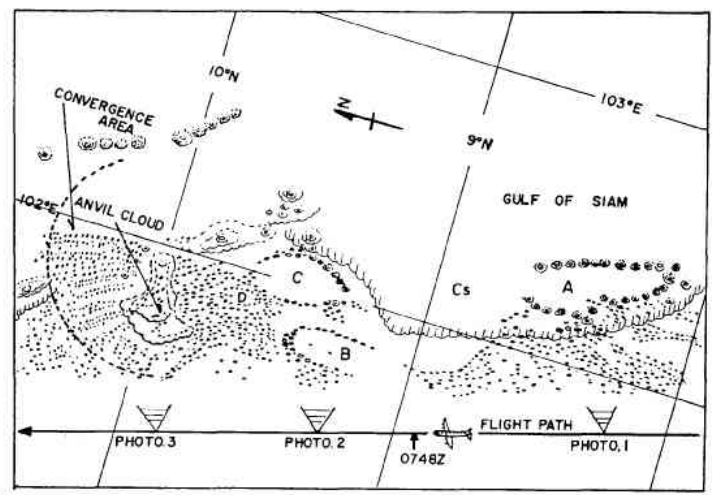

Fig. 3. Horizontal cloud distributions over the Gulf of Siam. The numbers on the flight path show the positions of photographies in Fig. 2.

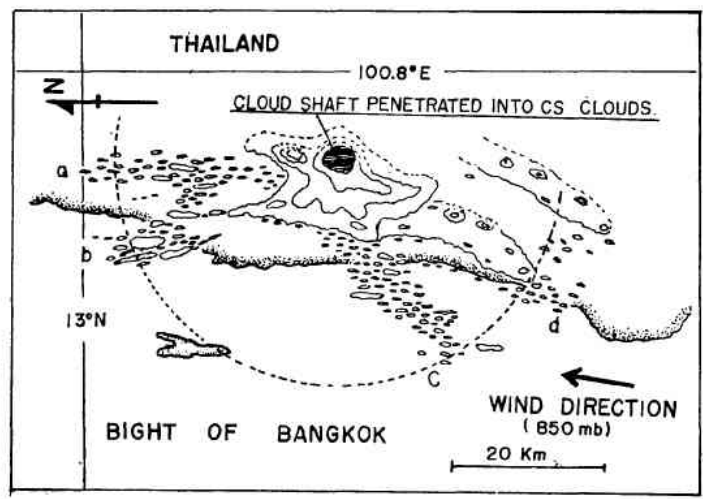

Fig. 4. Starfish-like cloud distribution over the coast near the eastern entrance of the Bight of Bangkok.

shaft of the towering cloud.

It was noted that several low-level cloud bands indicated by $a, b, \ldots d$ converged into the root of the towering cloud, in a starfish-like form. The region under the effect of the convergence of the low-level cloud bands was estimated about $60 \mathrm{~km}$ in the diameter, as shown by a dotted semi-circle. Each cloud band was composed of many fine streets.

\section{Consideration}

\subsection{The ring-shaped clouds over the Gulf of Siam}

As shown previously in Fig. 3, there were several ring-shaped cloud distribution, as designated by $B, C$ and $D$ over the area between $8^{\circ} \mathrm{N}$ and $10^{\circ} \mathrm{N}$. These cloud patterns of ring-shape perhaps show a sort of convective cells with descending motion in the center and ascending

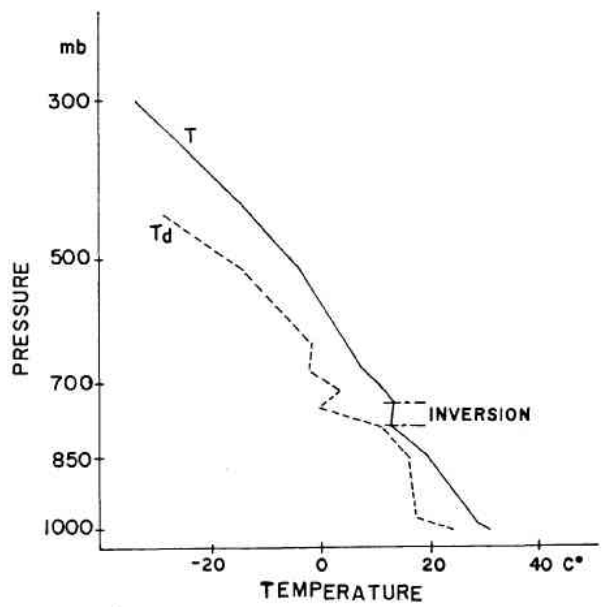

Fig. 5. Vertical profile of air and dew point tempertures at Songkla, Thailand.

motion at the periphery. No particular observation of vertical profile of the air was made near the cloud distributions, however, radiosonde data at Songkla, $250 \mathrm{~km}$ to the south of the observation point, might be available to consider the formation mechanism of the ring-shaped cloud patterns. The radiosonde data are shown in Fig. 5. The ascent curve of the air temperature $T$ shows an inversion layer near the $700 \mathrm{mb}$ level below which a moist layer with a thickness of about $50 \mathrm{mb}$ existed. This moist layer may correspond to the low-level cumulus cloud layer. From the result of the analysis, it was found that the ring-shaped clouds were located below this inversion layer.

Recently many ring-shaped cloud distributions were observed in satellite pictures. Krueger and Fritz (1961) reported that ring-shaped cellular patterns observed by a meteorological satellite had sizes of 30 to 50 miles in the diameter, and the patterns were formed below an inversion layer at a height of about $5000 \mathrm{ft}$ (about $1.5 \mathrm{~km}$ ). The size of the rings and the condition of the inversion were very similar to those of the present case. T. Vonder Haar et al. also reported that the ring-like cloud patterns of size 30 to $90 \mathrm{~km}$ were frequently observed in the tropical convergence zone. However, there are two distinct differences from the present observation. One is about the size of the individual cloud element. In the case of the satellite picture, the size of the element was in an order of 10 to 15 miles, while the size for the present case $(B, C$ and $D)$ was smaller than one mile. Cloud element of 
such a small size is unable to be observed in the satellite picture. The other is about the number of the ring-shaped patterns. In the satellite picture, numerous ring-shaped patterns were observed over a wide area, having an appearance of Benard's cells, however, in the present observation, only several patterns were found near the periphery of the convergence zone.

From the distinct differences described above, it is considered that the ring-shaped distribution of low-level cumulus clouds seen in the present observation was due to a convective air motion somewhat different from the Benard's cell type. Our ring-shaped distribution was very similar to the ring-shaped distribution seen in the Lake Okeechobee area in Florida, which was considered to be caused by differential heating between the lake water and the ground surface (Oliver and Oliver 1963). However, the authors considered that the present ring-shaped cloud distributions were caused by several downward motion areas accompanied by the convergence zone in its periphery.

The expected vertical cross-section of air currents in the ring-shaped distribution $(B, C)$ is given in Fig. 6. The vertical scale in the figure is enlarged by about eight times of the horizontal scale. Because the top of the element of cumulus clouds was lower than 2500 meters under which a temperature inversion layer existed, it was considered that the height of those upward motions at the periphery were very low and flat, being surpressed by the inversion layer. However, the downward air motion in the center came from a higher level of the convergence zone.

In the case of ring-shaped cloud distribution designated by $A$ in Fig. 3, the size of cloud element was fairly large and its height reached $5 \mathrm{~km}$. Therefore, this cloud distribution is the same in size as those of Benard's cell type cloud

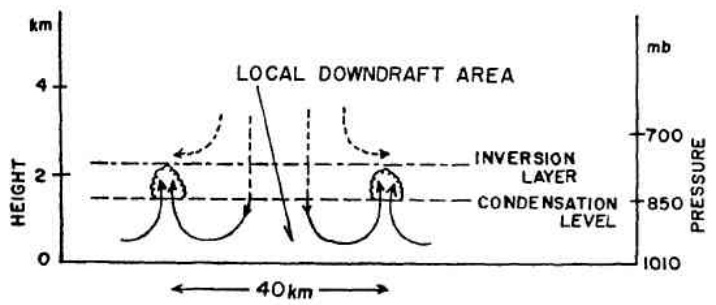

Fig. 6. Cross-section of a ring-shaped pattern of low-level $\mathrm{Cu}$ clouds which were under the inversion layer. The horizontal size of the cloud is exaggerated eight times. distributions in satellite pictures which were reported by Krueger and Fritz (1961), Hubert (1966) and Hardy (1968). However because our ring-shaped cloud distribution was isolated near the periphery of the convergence zone, it is considered that it was produced in the same mechanism as the several ring-shaped low-level cumulus cloud distribution.

It was seen in Fig. 4 that four cloud bands converged into the root of a towering cumulus cloud whose height reached the level of a dense cirrostratus cloud. The formation mechanism of these clouds is considered as follows. When the low-level wind was landed from the southward, several cloud bands were produced locally near the coast. Then the two bands $c$ and $d$ converged into a towering cloud which was active so as to reach and penetrated the cirrostratus cloud. As a result of the strong upward air motion, the other two cloud bands ( $a$ and $b$ ) to the leeward might be sucked into the root of the active towering cloud. The direction of the cloud bands shows that the prevailing wind was parallel to the bands.

A similar cloud distribution around a towering cloud was also observed near the Mekong River. Such a cloud distribution was also seen over the Malayan Peninsula, as reported in the previous paper (Chiyu and Magono 1967). Therefore, the authors considered that the distribution of this type of cloud frequently occurred in an isolated cumulonimbus cloud or an towering cumulus cloud, and the range of convergence area gives the size of the sucking area of an active isolated cloud.

\section{Conclusion}

Several ring-shaped cloud distribution were observed near a convergence zone in the tropical region. They were very low and the size of the individual cloud elements of the ring was as small as $1-2 \mathrm{~km}$. This cloud distribution suggests that there were a few center downward convection motions near the periphery of the convergence zone, however they were distinctly different from the Benard's cell type convection which were found in satellite pictures in the following points. They were very low and were scattered, and not so crowded as the Benard's cell type convection over a wide area.

Therefore, the authors concluded that the ringshaped cloud distributions were produced by 
several downward air motions near the periphery of the convergence zone.

Several cloud bands of low-level cumulus cloud seemed to converge into the root of a $\mathrm{Cb}$ cloud. From the distribution of the cloud bands, it may be possible to estimate the effective sucking area for the $\mathrm{Cb}$ cloud.

\section{Acknowledgments}

The authors wish to express their best thanks to the Flight Crew of Japan Air Line (Flight No. 714, Oct. 7 1965) for their cooperation in the observation, and to the Thai Meteorological Department, and the Singapore Meteorological Service, for their kind offering of the meteorological data for this cloud analysis. The authors also thank Dr. K. Kikuchi who took the $16 \mathrm{~mm}$ movie picture.

This study was made as a part of the project "Study on Clouds over the Pacific Ocean" supported by the U.S.-Japan Science Cooperation
Program. The expense of this work was defrayed by the funds of the Japan Society for the Promotion of Science.

\section{References}

Chiyu, T. and C. Magono, 1967: Three dimensional analysis of a tropical cumulonimbus cloud over the Malayan Peninsula. (Clouds over the Pacific Ocean: Part V). J. meteor. Soc. Japan, 45, 326331.

Kenneth R. Hardy, 1968: CPS-9-Radar Investigation of clear-air convection. 11th Weather Radar Conference, in Montreal, Canada, Session 5.

Krueger, A. F. and S. Fritz, 1961: Cellular cloud patterns revealed by TIROS I. Tellus, 13, 1-7.

Magono, C., K. Kikuchi and T. Kasai, 1969: Comparison of aerial pictures with satellite pictures. (Clouds over the Pacific Ocean: Part IV). $J$. meteor. Soc. Japan, 47, 227-234.

Oliver, V.J. and J.B. Oliver, 1963: Cloud patterns. Part I: Some aspect of the organization of cloud patterns. Mon. Wea. Rev., 91, 621-629.

\title{
熱帯地方の収束線周辺の雲の分布 \\ （太平洋の雲, その VI)
}

\author{
孫 野 長 治・周徳 \\ (北海道大学理学部地球物理学教室)
}

1965年10月, 旅客便の航空機を使ってシャム湾上の雲の分布を測定した.

収束線の南縁に沿うて数ケの輪状の雲の分布が観測されたが, これは気像衛星写真でよく見られるべナードセル状 の対流ではなくて，収束線周辺の下降流によるものと考えられる.

またひとでのような形の足をもった積乱雲や塔状雲が観測されたが，その収斂する足（雲）の形から，孤立した 一つの積乱雲や塔状雲の収斂域は大体直径 60 籸の面積と推定された. 